\title{
AUTHENTIC AUDIOVISUAL RESOURCES TO ACTUALISE LEGAL INTERPRETING EDUCATION
}

\author{
Ineke Crezee \\ Jo Anna Burn \\ Nidar Gailani \\ E-mail: icrezee@aut.ac.nz \\ Auckland University of Technology
}

\begin{abstract}
New Zealand Aotearoa is an English-medium country and a home to a high number of minority migrant groups speaking over 160 different languages. To cater to the needs of such a diverse population, the Interpreting and Translation Team at Auckland University of Technology has developed a language-neutral pedagogy using a range of innovative teaching methods. One method is the use of authentic audiovisual material incorporating extracts from murder trials to raise awareness of courtroom discourse in general, and lawyers' questions in particular. The aim of this study was to ascertain to what extent audiovisual clips are beneficial in legal interpreter education. After viewing audiovisual clips, students posted their practice on the university website. These recordings were then de-identified and formative feedback was given by language-specific markers as per standard performance based criteria. Students' evaluation and comments from pre- and post-intervention surveys were analysed and form the basis of a discussion.
\end{abstract}

\section{Zusammenfassung}

Neuseeland ist ein englischsprachiges Land, in dem jedoch mehr als 160 verschiedene Minoritätengruppen von Immigranten ihre eigene Sprache haben. Um den daraus entstehenden Bedürfnissen gerecht zu werden, hat das DozentInnen-Team für Translationswissenschaft an der Auckland University of Technology eine sprachneutrale Pädagogik entwickelt. Diese beinhaltet eine Reihe von innovativen Lehrmethoden für das Dolmetschen im juristischen Bereich. Eine dieser Methoden ist die Einbeziehung von authentischem audiovisuellem Material mit Extrakten aus Mordprozessen, 
um das Verständnis von Gerichtsdiskursen im Allgemeinen, und im Besonderen von Anwaltsfragen zu verbessern. Das Ziel unserer Studie war zu prüfen, inwieweit audiovisuelle Clips für das DolmetscherInnen-Training im juristischen Bereich hilfreich sind. Die teilnehmenden Studenten luden ihre Übersetzung dieser Clips auf eine universitätsinterne Webseite hoch. Die übersetzten Texte wurden anonymisiert und Spezialisten der verschiedenen Zielsprachen gaben den Studenten formende Revisionen und Bewertungen anhand standardisierter Kriterien. Die Bewertungen der Studenten sowie ihre Antworten auf Umfragen vor und nach der Intervention wurden analysiert und formten die Basis einer Diskussion.

Keywords: Interpreter training. Legal language. Authentic audiovisual material. Situated learning.

Schlüsselwörter: Dolmetscherausbildung. Rechtssprache. Authentisches audiovisuelles Material. Situationsgebundenes Lernen.

Manuscript received on June 28, 2014

and accepted for publication on September 19, 2014. 


\section{Introduction}

New Zealand Aotearoa has a small population (4.5 million) but a landmass roughly equivalent to the United Kingdom or Japan. Of the three official languages, English, Māori and New Zealand Sign Language, English is by far the most widely spoken and the vast majority of governmental, educational and legal business is conducted in English. However New Zealand has an extremely diverse population with over 160 different spoken languages and dialects, and has been classified by Spoonley and Bedford (2012) as being one of a small number of super-diverse countries (Vertovec 2007). The exponential growth in migration in recent decades has necessitated a corresponding growth in interpreter and translation services in general, and in the courts in particular.

On signing the Treaty of Waitangi in 1840, New Zealand became a British colony and adopted the British Westminster system of government. This included inheriting English common law and the adversarial system of setthing disputes in criminal courts. The adversarial system involves defence and prosecution lawyers attempting to convince the fact finder (judge, or jury in more serious criminal cases) of the veracity of their version of events. This requires the prosecution or defence lawyer to 'tell the story' through a combination of physical evidence and witness testimony. The lawyer does this by using language to exert powerful situation control over the witness (Lakoff 1985, Luchjenbroers 1993). Of particular importance, the lawyer also uses a variety of carefully framed question types to elicit selective 'helpful' information which contributes to the narrative as interpreted by the lawyer. Conversely the lawyer may use carefully selected questions to discredit, or at least cast doubt on, unhelpful testamentary evidence elicited from the opposing side's witness. Thus the prosecuting lawyer strives to convince the judge or jury that the case has been proven 'beyond all reasonable doubt', whilst the defence counsel attempts to cast doubt on the prosecution version of events. Previous studies by Berk-Seligson (2012), Lee (2009), Rigney (1999) and Hale and Campbell (2002) have shown that carefully chosen questions are often not interpreted accurately in court. This may be because the interpreter 
fails to divine the subtleties of the question's pragmatic intent, or simply lacks the linguistic skills to render an accurate interpretation.

At present there is no legal requirement in New Zealand for court interpreters to undergo registration or training; however, the New Zealand Society of Translators and Interpreters (NZSTI) operate a voluntary scheme of registration and publish an online directory of members' names. Ordinary members must satisfy the NZSTI requirement that they have completed an approved course of study in a New Zealand institution, or satisfy the membership criteria in another way such as long term employment within an interpreting or translation organisation that provides professional development and supervision to employees. Translators and interpreters with lesser qualifications may apply for affiliate membership. The Ministry of Justice now requires court interpreters to hold a minimum of NZSTI affiliate status, and members and affiliate members of NZSTI may command higher rates of pay for interpreting assignments. However there are still a number of non-NZSTI interpreters working in the legal field. Due to the often spontaneous nature of legal interpreting work, interpreters may be called at short notice to work in police stations, prisons, lawyers' and probation offices as well as courts and tribunals. Although the Ministry of Justice has a memorandum of understanding with NZSTI to use full members in the first instance and affiliate members where ordinary members are not available, this does not always happen in practice. The students who took part in this study were all undertaking a NZSTI approved course of study at the authors' university.

The focus of this study is to evaluate the use of authentic audiovisual material to facilitate the accurate interpreting of legal language, and in particular the genre and register of different question types during witness questioning in criminal court cases. The methodology of the study and nature of the clips will be described and student response as measured through pre- and post-intervention surveys discussed. The pedagogical principle of situated learning will be briefly examined, as it is used in interpreter education at the authors' university.

\section{Background}

Education delivery has changed radically following globalisation, the advent of information technology and the worldwide web. Kiraly (2000) points out that there is a lack of educators researching their student cohorts to assess the ever changing knowledge and skills needed by those students. The authors' university aims to foster professional competence in graduates based on the reality of the contexts they can expect to be working in. Interpreting professionals 
need to be able to gather the information required for a task, as it occurs. In order to do that, an underlying understanding of genres and socio-pragmatic norms is essential. A social constructivist approach to interpreter education has as its key the concept of learning through authentic action.

Kiraly's (2000) six principles echo the nine of situated learning (Lave \& Wenger 1991). Kiraly proposes that students should find several appropriate solutions arising from the authentic texts provided in class. He further believes that teachers should create a scaffold for learning and gradually allow students to safely construct their knowledge through practice.

Since its inception in 1998, the advanced legal interpreting course at the authors' university has included a reflective observation journal in which student interpreters describe their reflections on the performance of a court interpreter in action. Student interpreters are required to attend a court case over the course of several days, to observe the interpreter and reflect on the role of the interpreter in the courtroom. Students have relayed that they value this experience and find it very useful to gain an insight into the role of a practising court interpreter.

Although undoubtedly beneficial to students' learning outcomes, courtroom observation does not completely fulfil the students' needs. Firstly, in the language-neutral classroom there may be students with a dozen different languages and it may not be possible to find trials or other court hearings involving each interpreter for his/her language. Secondly, while students can observe authentic courtroom interactions, they are not able to use these to test their own interpreting skills. Thirdly, even if they whisper along with the professional interpreter in their own language in order to practice interpreting, they are unable to receive feedback on their interpreting.

\section{Literature review}

\subsection{Court interpreting}

Kinnunen (2011) focuses on the challenges of multilingual court work in Finland with the aim to describing, based on one interpreting event, the kind of problems occurring in the courtroom in relation to the collaboration of court interpreters and the legal professionals. Her statement that, "legal reasoning premised on translated legal texts or on interpreted oral evidence may often be a complex assignment for a judge" (2011: 2) clearly evidences the considerable responsibility weighing on interpreters' shoulders on any given day inside the courtroom. 
Kinnunen (2011) suggests a number of ways for efficient collaboration between interpreters, legal professionals and facilitators, in order to better handle the complex process of courtroom interpreting. These include, for example, initial discussions about interpreting procedures before the interpreting commences inside the courtroom, and providing a contact person who can assist transfer necessary documentation to the interpreter so that they have some background material and can prepare for a case - this is especially a valid exercise in complex cases, however in the New Zealand setting current legislation prevents court contact staff from providing interpreters with any information whatsoever. Kinnunen (2011) also proposes a multi-professional team work and expertise sharing, via unofficial meetings between the two professions where problems of collaboration and learning to know each other's work would also be important for the general development in the field of interpreting. In Australia, Hale and Napier (2013) carried out a range of surveys to find out views of court staff (magistrates and others) and interpreters on court interpreting, however no research of the kind has been carried out in the New Zealand setting.

Interestingly, Kinnunen (2011) expresses what most of us seasoned interpreters have long been calling for situated learning to understand translating or interpreting as a necessary action in a larger activity system. This fits in with the Vygotskian approach to learning and development, as outlined by John-Steiner and Mann (1996) and Daniels (2008). Ideally, the trainee or apprentice is taken into the setting to practice and develop and receive feedback on his/her performance. However none of this is currently possible within the New Zealand court interpreter education setting, for a variety of reasons. The situated learning approach described in this paper has been chosen to provide trainee court interpreters with an opportunity to not only interpret authentic courtroom language, but to also have access to visual cues, and receive individualised language-specific feedback on their performance.

As the professions of interpreting and translating emerge from their infancy stage in New Zealand, legal professions are becoming more adept at utilising this much needed service in our mutli-lingual and multi-cultural society. Kinnunen (2011) notes that interpreting has certain goals in a multilingual court system, and the actions of interpreters form parts of it. Furthermore, she points out that when we become competent court interpreters, we learn to use the language in an adequate way in that context of activity, and in order to learn the discourse of the legal community, a newcomer has to be able to participate legitimately in the processes of the expert community (Lave \& Wenger 1991). Lave \& Wenger (1991: 110) advocate that newcomers 
should "have broad access to arenas of mature practice". This again fits in with the 'legitimate peripheral participation' approach (Lave \& Wenger 1991) followed in interpreter education at the authors' university.

At Auckland University of Technology, student legal interpreters have access to mature practice in that they are asked to observe a practising court interpreter in action. They are asked to reflect on the interpreter's role and performance and on where the interpreter fits in relation to the other courtroom actions.

Hale (2010) discussed challenges to court interpreters in relation to grammatical and discourse factors. Hale (2010: 247) noted that, given languages differ at all levels of the linguistic hierarchy, "interpreters need to be competent at all levels in each language, and be able to make judgments about what aspects of the original utterance to sacrifice in order to achieve a pragmatic rendition when interpreting." However, Hale acknowledges the difficulties in court interpreting, where subtle changes to utterances can lead to changes in evidence and evaluation of witness credibility. Hale (2004: 38-39) describes questions (asked by each counsel and translated by each interpreter) used in a study conducted with thirteen English-Spanish interpreted Local Court hearings in New South Wales, Australia, between 1993 to 1996. She categorises these questions into three types: interrogatives, declaratives, and imperatives.

The question categories, according to Hale (2004), are used by the Cross-Examination and Chief-in-Examination teams; however, the most commonly used type was found to be positive polar interrogative (e.g. "Was the telephone he had in his pocket his phone?"). Nevertheless, Hale notes that when interpreted to Spanish, the nature of these question types were sometimes altered, where the majority of questions were interpreted as simple declaratives with no rising intonation.

\subsection{Approach to interpreter education}

Based on her comparison of the performances of expert versus novice interpreters, Liu (2001) argued the importance of real world experience in gaining interpreting expertise, through the acquisition of domain specific skills. Ryu (2009: 256) suggests that "the world outside the classroom doors" might be "a better learning arena in many areas" when it comes to offering students a situated learning experience. Hale (2013) also emphasised the importance of interpreters being prepared to work in specialised settings such as healthcare and the courts. The authors agree, but would add that involving trainee interpreters in situated learning "in the real world" is not always feasible or safe for either students or the parties they might interpret for as 'trainees'. 
The authors have therefore attempted to implement a situated approach to interpreter training that includes the use of innovative technologies in a language-neutral classroom.

The master-apprentice model referred to by Pöchhacker (2010) is very useful in interpreter education. However, in language-neutral interpreter education, the master-lecturer is not able to provide immediate feedback to trainee interpreters in terms of their performance, necessitating the input of individualised feedback provided by (anonymous) master language specialists.

\section{Methodology}

The aim of this study was to ascertain to what extent audiovisual clips are perceived to be beneficial in legal interpreter education. Hale \& Napier (2013) provide an excellent guide to possible research methods. The methodology chosen here included both audiovisual interpreting tasks to be performed by participating student interpreters and participants' views on the use of such tasks both pre- and post-study. This paper will describe an intervention in an interpreter classroom preceded and followed by a survey to gauge student response to the intervention.

\subsection{Sample}

Seventeen student interpreters completed the first audiovisual interpreting practice and received feedback on their performance. All participants were enrolled in the first of two advanced interpreting papers. Students were undertaking these papers either as part of a Bachelor Degree in Interpreting or as part of a Graduate Diploma in Interpreting. This meant that all Bachelor degree students and most Graduate Diploma students had already completed two introductory interpreting papers (Theory and Practice of Interpreting and Societal Contexts) as well as Oral Discourse for Interpreters. Some of the Graduate Diploma students had opted to take all eight papers of the Graduate Diploma concurrently, and, therefore, they lacked some of the gradual development of skills enjoyed by their peers. Students were able to take the legal interpreting paper in question either online, or on site, in the classroom. Participating students were all in the classroom cohort of the legal interpreting paper, since the lecturer was able to ensure that the latter all completed the interpreting practice at the first attempt.

Only fourteen of them completed the pre-intervention survey, while only thirteen participants completed the post-intervention survey. We will therefore consider that the sample consisted of fourteen students. 
Student participants represented a range of seven different languages: Mandarin, Korean, Samoan, Spanish, Farsi, Guajarati and Japanese. A majority of participants were aged 25 and over and had already completed university studies in their country of origin. This is significant as more mature student interpreters tend to be more aware of legal cases reported on in the media than students who have only just completed secondary education.

\subsection{Audiovisual clips}

Audiovisual clips of authentic New Zealand courtroom interactions were found on YouTube. Web references for each clip have been provided with the description of each clip, in Section 4.2.1 below. Postings contained scenes from trials which had been shown as part of news broadcasts on national television. YouTube postings had been in the public arena for at least 12 months. The researchers discussed which clips to use and in what order to show them to the students.

It was decided to provide students with clips which showed a variety of different question types from different stages of the examination and cross-examination process. The discourse used by the lawyers in the audiovisual clips conformed to that described by Hale (2004) with all cross-examination question types used for cross examination fitted in with those listed in her categories (Hale 2004: 38-39). The adversarial nature of the cross-examination samples in the audiovisual recordings was associated with highly formulaic, 'frozen' (Joos 1968) patterns of language, a high use of modal verbs and conditionals, as well as interrogative and imperative structures. Responses were elicited through the use of complex questioning modes involving the double negative or other structures, as outlined in the examples given above. Textual features of the lawyers' argumentative discourse types included endophoric references (both anaphoric and cataphoric) and lexical reiteration.

The researchers decided to only provide students with three clips, posted in weeks 3, 6 and 9 of Semester One of 2014. This was done in order to not overload the students with additional tasks in what is already considered a very time-intensive course. It was also done to allow time for feedback from language assessors to be passed back to participating students. Week 3 was specifically chosen because students were already somewhat familiar with legal language, having had three weeks of legal studies lectures and legal interpreting exercises recorded in audio mode.

A succinct description of the content of each clip will be given below. 


\subsubsection{Content of audiovisual clips}

All three video clips related to courtroom interactions consisting of the examination and cross-examination of witnesses at murder trials. All three trials had been extensively reported on in the New Zealand media at the time, but were perhaps no longer in the public mind as much by the time the audiovisual clips were posted.

Prior to posting the clips on the learning management system, a brief discourse analysis was undertaken by one of the researchers in order to decide in what order the clips would be posted. Pedagogically it would be best to post the least challenging clip first and the most challenging last. The level of challenge was based firstly on the type of examination witnesses were subjected to, with cross-examination being considered the more challenging type of encounter for student interpreters to work with (Hale 2004). A second criterion for the level of challenge was the proportion of legal terminology that beginner student interpreters might not be immediately familiar with, such legal phrases as 'I put it to you that...' and 'he was satisfied that'. Following this analysis the order of the clips was decided upon. Clips have been described in more detail below, together with some background information and salient details.

\section{Clip One: Examination of witness at a murder trial}

Clip One revolved around a defendant referred to as "EM" who was standing trial for the murder of his brother-in-law in 2010 (retrieved from: https:// www.youtube.com/watch?v=fOgZzrXA0EU). In court, EM had already admitted to vandalising his brother-in-law's house in 2008 and burning the old farm houses which were being relocated to make way for a new house that was later built on the site.

EM's wife, AG, was being questioned by the prosecution lawyer. In the course of the trial it became obvious that she was convinced of her husband's guilt, and we therefore hesitate to refer to this questioning as a cross-examination. Lexical items included mainly everyday terms, although the examining lawyer asked AG several long-winded questions full of reiterations and false starts. Some of these could be classed what Hale (2004: 38) calls positive polar interrogatives. Examples include:

(1) On the $24^{\text {th }}$ of October 2008 , during the evening, do you recall, erm, any noise at all that disturbed your sleep, outside the house?

(2) You are obviously aware of the fire damage, by going [...] from what you learnt? 
(3) Do you recall erm do you have any recollection at all of what Mr M was doing that night?; and: What I want to know from you is, from October 2008 until his arrest in April 2011 did he conduct himself in any way that made you suspect that he'd been involved?

(4) Was there any change in his behaviour, either immediately after the arson that you can... have you since recalled or have since thought about or has since struck you?

Overall, this clip was considered to be a good introductory clip for students to work with.

Clip Two

Clip Two (https://www.youtube.com/watch?v=U128mBnirp0) involved the cross-examination of a Police detective who had accompanied the Police doctor while the latter examined the bodies on a multiple fatality crime scene to certify the deaths. This clip shows the defence lawyer taking the police officer on a tour of the house. The language used is fairly simple, with multiple references to crime scenes and bodies. Collocations and phrases included: 'from scene to scene', 'viewing the bodies', 'examining the bodies', 'not to disturb the bodies in any way', 'he was satisfied that $\mathrm{x}$ was obviously dead', and 'did he examine the pulse on each of the other victims?'

This clip contained a few questions which were neither overly long nor complex. Questions included:

(5) How careful or otherwise did he appear to be in each scene?

(6) [a]nd when he continued to film is that in the same way as you described in Scene A from the doorway or did he go into the room on this occasion?

(7) Erm, do you have any recollection of light, other than that that was being provided by Mr G?

(8) When you say light thing, was it on top of it, or part of the equipment itself?"

Conditionals were used sparingly during this cross-examination. An example was: "Oh he would certainly have had to go down that little corridor, but he would have had to push the curtain aside at the end," and "Erm, based on memory I wouldn't like to say." 
Clip Three

Clip Three (https://www.youtube.com/watch?v=7vjNSZlHVyo) showed the cross-examination of the ambulance officer who found the defendant in the same murder trial shown in Clip Two. The ambulance officer testified that he thought the defendant was pretending to have fainted. This became the subject of intense adversarial questioning by one of the Defence lawyers, in an obvious attempt to undermine the credibility of the witness.

Seemingly in an attempt to catch the witness off guard, this lawyer used several very long and complex questions, such as:

(9) So if medical evidence is given by a medical specialist that all of these symptoms and what is being described is consistent with someone fainting and recovering from a faint, you wouldn't disagree with that, would you?

(10) Well, I just want to pause here. The difference between you and a medical qualified person with a degree in medicine is that you are taught to manage symptoms, and the medical people do the diagnosis, would you accept that?

Other persuasive phrases included:

(11) Well, I come back and I'm giving you an opportunity again [...].

\subsection{Data collection}

Data collection was aimed at capturing students' opinions of the use of audiovisual interpreting practice before and after the study, as well as at collecting interpreted tasks for feedback and analysis.

Data collection included the following:

- Step 1: Identifying publicly available audiovisual clips of authentic courtroom interaction.

- Step 2: Transcribing the clips and converting them from YouTube postings into mp4 files.

- Step 3: Inserting pauses and blank screens into the resulting mp4 files to allow students to interpret in the blanks.

- Step 4: Posting audiovisual interpreting tasks on the Online Learning Management System (OLMS) prior to the session in which the purpose of the intervention was explained to students.

- Step 5: In week 2: Handing out participant information sheets, explaining the intervention and handing out consent forms. 
- Step 6: In week 2: Handing out pre-intervention surveys to students who had indicated their willingness to participate. Collecting the same afterwards.

- Step 7: In week 3: Students posting their interpretations on the learning management system at the first attempt of interpreting the authentic courtroom interactions with the aid of the audiovisual practice clips.

- Step 8: De-identifying student recordings and posting them on an online page accessible only to selected language assessors.

- Step 9: Language assessors providing feedback on student interpreter performance.

- Step 10: De-identified feedback from language assessors passed back on to the students.

- Repeating steps 7 to 10 in Weeks 6 and 9.

- Step 11: Handing out post-intervention surveys to students who had indicated their willingness to participate. Collecting the same afterwards.

Steps 1, 2 and 4 were carried out by the researchers, while step 3 was carried out by the technical support person. Steps 5 to 10 and Step 11 were carried out by an independent third party who was not in a student-teacher relationship with the students.

Prior to commencing the study, approval was obtained from the University ethics committee, and suggestions from the committee were implemented in the study. It was emphasised at all stages that participation was purely voluntary and researchers-teachers would not know which of the students had participated until after all final exam results had been approved by the examination board. Thus, all tasks were posted on OLMS, and all students in the legal interpreting classroom were able to complete the tasks and post them online. However, only the participants who had consented to participate received feedback on their individual interpreting performance on the tasks.

\subsection{Analysis}

The analysis of both types of data collected focused on the following:

- Analysis of miscues or interpreter errors

- Pre- and post-study surveys and analysis thereof

- Comparing findings of the miscue analysis and the pre- and poststudy analysis 
Miscues are defined as interpreter errors and various taxonomies have been proposed (e.g. Wixson 1979). A detailed analysis of omissions and changes was still in progress at the time of writing and will be found in another paper (Crezee, Grant \& Burn, in progress).

\section{Findings and discussion}

In the study described here, a small sample of trainee court interpreters practised interpreting with authentic courtroom interactions and received feedback on their performance. Students were asked to complete a pre-intervention survey in week 2 before undertaking interpreting practice to audiovisual clips in weeks 3, 6 and 9 and completing a post-intervention survey in week 9. Pre- and post-intervention survey responses were analysed and are presented in Section 5.1.

\subsection{Pre-and post-intervention responses and comments}

Students were asked to evaluate the importance of them being aware of authentic courtroom language on a scale from 1 (Not important at all) to 5 (Extremely important):

Table 1: Importance of authentic courtroom language

\begin{tabular}{|c|c|c|c|c|c|c|}
\hline & \multicolumn{5}{|c|}{ Student evaluation } & \multirow{2}{*}{$\begin{array}{c}\text { Total } \\
\text { number of } \\
\text { students }\end{array}$} \\
\hline & $\begin{array}{l}\text { Not } \\
\text { important } \\
\text { at all }\end{array}$ & $\begin{array}{l}\text { A little bit } \\
\text { important }\end{array}$ & $\begin{array}{l}\text { Quite } \\
\text { important }\end{array}$ & $\begin{array}{c}\text { Very } \\
\text { important }\end{array}$ & $\begin{array}{l}\text { Extremely } \\
\text { important }\end{array}$ & \\
\hline Pre- & & & & $5(36 \%)$ & $9(64 \%)$ & 14 \\
\hline Post- & & & $1(8 \%)$ & $4(31 \%)$ & $8(61 \%)$ & 13 \\
\hline
\end{tabular}

Pre-intervention comments included: "If you are not aware of what actually happens, you will be at a loss when you start working as a court interpreter" (from a participant who chose "extremely important"); "We get experience of the courtroom before we actually have a chance to go there" (this participant likewise opted for "extremely important"). Another student who chose "extremely important" said: "We're preparing ourselves for being capable of working in real courtrooms where authentic courtroom language is used". A fourth participant stated: "Evidence of authentic courtroom language will give interpreting students necessary knowledge and confidence" (this participant also chose "extremely important"). 
After the intervention, student comments included: "As a student, it's hard to experience real courtroom discourse often" (this participant opted for "very important" in their reply). While another student (who rated their response as "extremely important") wrote: "What actually means is [it is] very important and the interpretation should be done to convey the actual meaning rather than the literal meaning." Yet another student stated: "Because we don't use those languages in our daily life so it's important to know or learn beforehand" and s/he too selected "extremely important".

Students were also asked to rate their perceived awareness of the nature of authentic courtroom language on a scale from 1 to 5 . Responses may be found in Table 2 below.

Table 2: Awareness of authentic courtroom language before and after interpreting the audiovisual clips

\begin{tabular}{|c|c|c|c|c|c|c|}
\hline & \multicolumn{5}{|c|}{ Student evaluation } & \multirow{2}{*}{$\begin{array}{c}\text { Total } \\
\text { number of } \\
\text { students }\end{array}$} \\
\hline & $\begin{array}{c}\text { Not aware } \\
\text { at all }\end{array}$ & $\begin{array}{c}\text { A little bit } \\
\text { aware }\end{array}$ & $\begin{array}{l}\text { Quite } \\
\text { aware }\end{array}$ & $\begin{array}{l}\text { Very } \\
\text { aware }\end{array}$ & $\begin{array}{c}\text { Extremely } \\
\text { aware }\end{array}$ & \\
\hline Pre- & $2(14 \%)$ & $8(57 \%)$ & $4(29 \%)$ & & & 14 \\
\hline Post- & & $2(15 \%)$ & & $4(31 \%)$ & $6(46 \%)$ & 12 \\
\hline
\end{tabular}

One pre-intervention participant (who selected "not aware at all") noted, "We normally don't get the chance to be familiar with anything to do with courtrooms, unless we're related to the case somehow."

A post-intervention survey participant commented, "I have certainly got more used to the atmosphere" (and opted for "very aware"). Another, "Visual images help to guess the correct meaning according to context"; Student 8 seemed to be struggling, noting that "It is really hard, and you feel/see the pressure"; while Student 11 was more reflective: "I have seen from this material the emotions and question types, the lawyers engage."

However, one student expressed feeling more confused after interpreting the audiovisual clips. This student commented: "I became more confused... because most of the audiovisual clips have no brief at all, sometimes there are no titles. It makes it hard for students to interpret, especially the first few sentences, as there are no clues about what the clip is about" (and opted for "A little bit aware"). The cases reflected in the audiovisual clips had been widely reported by all New Zealand media, so perhaps this student had not followed them. 
Students were asked to comment on the perceived benefits of the audiovisual legal interpreting practice clips both pre- and post-intervention (Hale \& Napier 2013).

Table 3: Perceived helpfulness of seeing authentic courtroom language used in context, on audiovisual clips posted for interpreting practice

\begin{tabular}{|c|c|c|c|c|c|c|}
\hline & \multicolumn{5}{|c|}{ Student evaluation } & \multirow{2}{*}{$\begin{array}{c}\text { Total } \\
\text { number of } \\
\text { students }\end{array}$} \\
\hline & $\begin{array}{c}\text { Not } \\
\text { helpful at } \\
\text { all }\end{array}$ & $\begin{array}{l}\text { A little bit } \\
\text { helpful }\end{array}$ & $\begin{array}{l}\text { Quite } \\
\text { helpful }\end{array}$ & $\begin{array}{c}\text { Very } \\
\text { helpful }\end{array}$ & $\begin{array}{c}\text { Extremely } \\
\text { helpful }\end{array}$ & \\
\hline Pre- & & & & $6(43 \%)$ & $8(57 \%)$ & 14 \\
\hline Post- & & & $1(8 \%)$ & $6(46 \%)$ & $6(46 \%)$ & 13 \\
\hline
\end{tabular}

Interestingly, some students gave conflicting answers before and after the intervention. Please refer to the discussion section in this article for further details.

Pre-intervention, one student advised: "We can get a taste of what is to be expected before going to the courtroom to interpret and find ourselves helpless" (and selected "extremely helpful"). Another participant noted that it "[w]ould be helpful to see utterances and gestures of the speaker, with court matters, people's lives are affected by the decisions made and therefore very important from my point of view" (and similarly selected "extremely helpful"). One survey taker selected "quite helpful" and qualified his reply by explaining "[a]t this point, my interpreting skills focus on note-taking, so my sight is always looking at my notes. So audiovisual practice is not quite useful; however, if I have more experience, it would be useful." He was the only post-intervention survey taker to choose "quite helpful", however his explanation contributed to our understanding of why the evaluation of the perceived helpfulness of the audiovisual clips appeared slightly less positive for participants on the whole.

Post-intervention, one survey respondent, who chose "extremely important", stated: "[r]ather than listening to the intonation of the same lecturer, various settings and speaking patterns are helpful." While another respondent wrote:

(12) [this] provides really helpful practice before going into real work $[\ldots]$ we need to hear the actual wordings and sentences uttered by legal professionals, as they are the real deal, compared to a simply 
written and recorded version. Also the pace and pronunciation seems quite different.

A third participant (who chose "very important") wrote: "Because the video clips were authentic".

Table 4 shows that following the intervention, students still felt there was a place for interpreting practice recorded in audio mode only.

Table 4: Table 4: Perceived helpfulness of practising with authentic courtroom language recorded as audio interpreting exercises only

\begin{tabular}{|c|c|c|c|c|c|c|}
\hline & \multicolumn{5}{|c|}{ Student evaluation } & \multirow{2}{*}{$\begin{array}{c}\text { Total } \\
\text { number of } \\
\text { students }\end{array}$} \\
\hline & $\begin{array}{c}\text { Not } \\
\text { helpful at } \\
\text { all }\end{array}$ & $\begin{array}{l}\text { A little bit } \\
\text { helpful }\end{array}$ & $\begin{array}{c}\text { Quite } \\
\text { helpful }\end{array}$ & $\begin{array}{c}\text { Very } \\
\text { helpful }\end{array}$ & $\begin{array}{c}\text { Extremely } \\
\text { helpful }\end{array}$ & \\
\hline Pre- & & & $1(8 \%)$ & $5(42 \%)$ & $6(50 \%)$ & $12 *$ \\
\hline Post- & & $1(9 \%)$ & $3(27 \%)$ & $4(36 \%)$ & $3(27 \%)$ & $11^{*}$ \\
\hline
\end{tabular}

*Some pre-test and two post-test participants did not tick any options for this question

One of the final questions asked students to comment on what they believed to be the best way to increase their ability to recognise and accurately interpret authentic courtroom language.

Pre-intervention comments were largely positive and reflective of authentic courtroom practice as useful and educative, and included: " $[\mathrm{t}]$ o sit amongst a case/role-play scenario; our weekly terminology sheets" (referring to the sheets with terminology handed out before audio practice in the computer lab each week); "videos of the actual court sessions with an interpreter"; "watch videos about a case happening in the courtroom"; and "be exposed to the actual situation, to observe and familiarise ourselves to the real action."

Two post-intervention participants did not tick an option, but did offer an unrated opinion, with one stating: "[a]udiovisual clips on different context would be very helpful", and the other: "[a]udio exercises could be used in order for students 'to be exposed' to different types of the controversial settings".

Student participants were asked to comment on what they believe(d) to be the best way to practise interpreting in general. Replies pre- and post-intervention varied with post-intervention replies appearing to have been favourably influenced by the audiovisual interpreting practice experience. 
Pre-intervention comments about best ways to practice interpreting included:

(13) Pick up conversations in real situation and interpret. Use TV and radio or similar sources to get used to the speed and accent in spoken English in action; through practice opportunity in the courtroom; just lots and lots of practice and perhaps getting some tips from an actual interpreter who is still working in the field.

Post-intervention comments included: "To be able to observe (if not physically, at least visually) and to constantly observe interpreter [sic] in action so we could be well-aware of what to be expected -> make less mistakes when working in the real field"; "get into the real situation and learn the authentic language used there; practise as often as possible"; "audiovisual clips will be most helpful at this stage" and: "Attending the courtroom as an observant (as we did in Courtroom observation) is the best way to practise interpreting."

\section{Discussion and conclusion}

This article has presented a classroom intervention involving the use of authentic audiovisual courtroom clips with a cohort of students in a legal interpreting course. Student participants were instructed to interpret at their first exposure to the audiovisual clips. This was done in an attempt to mimic the real courtroom interpreting situation, in which interpreters have no time to listen to utterances a second time. Students were given quite minimal information about the audiovisual clips, and this too reflects the real situation in New Zealand courtrooms, where in reality interpreters are often not given any, or receive only very basic facts about the case in which they are about to interpret.

Interestingly, in the current study, initial responses to the clips showed that some participants had no background knowledge whatsoever of these court cases which were widely reported in the New Zealand media in the years leading up to the classroom intervention. Certainly it became clear that none of the students had followed the court cases closely, although this may also have been related to the fact that these cases lasted for weeks.

The limitations of the study included the fact that it involved only a small classroom cohort, with the remainder of students taking the paper online as explained in the Methodology section. The online students were not allowed to participate as the lecturers could not be sure they would interpret the audiovisual clip at first attempt. 
In addition, there was no control group. This would have consisted of a group who interpreted the same dialogues in audio mode only, without the benefit of the visual clues. This was because the authors felt it would have been unfair to deprive any of the students of the opportunity to interpret a real authentic courtroom interaction by audiovisual means.

This article has looked at pre- and post-intervention responses by students, with the analysis of interpreting performance reported on in another article (Crezee, Grant \& Burn, in progress).

As expected, all student participants reported increased awareness of the nature of authentic courtroom language, although one stated that she felt more confused due to the lack of briefing. The court cases in question had been widely reported by the media, so this response partly reflected the student's lack of awareness of such cases. It must be added that while students were normally given terminology sheets prior to audio interpreting practice, they were not given any brief as to the nature of the case the audiovisual clip had been taken from. Briefing was omitted on purpose, as New Zealand court interpreters never receive any information about the case they are about to interpret for, as this is prohibited by law. Hence, while the lack of briefing added to the authentic nature of the exercise, the authors would consider giving students some background information if the intervention is repeated in future. This is because normally interpreters would become more familiar with the nature of a given case in the course of acting as an interpreter for that case.

As stated, the replies given in relation to the perceived helpfulness of seeing authentic courtroom language used in context through audiovisual interpreting practice clips posted differed pre- and post-intervention. Pre-intervention, all participants felt that audiovisual courtroom clips would either be very helpful or extremely helpful. Post-intervention, one survey taker selected "quite helpful" and qualified his reply by explaining that he partly attributed this to his own lack of experience in interpreting and taking notes at the same time. However, he qualified this reply by stating: "At this point, my interpreting skills focus on note-taking so my sight is always looking at my notes. So audiovisual practice is not quite useful; however, if I have more experience, it would be useful." His reply explains why the evaluation of the perceived helpfulness of the audiovisual clips was slightly less positive for the group as a whole. However, the participant did qualify his statement by saying that it would be useful once his own experience in interpreting/notetaking improved. Fourteen students had participated in the pre-intervention survey, but only twelve had completed the post-intervention survey. The 
missing participants may well have felt that the clips were either very helpful or extremely helpful - we can only speculate.

As expected, student responses indicated an increased preference for audiovisual as opposed to audio-only interpreting clips post-intervention. Having had a taste of audiovisual interpreting, students were less enthusiastic about having audio only interpreting practice following the intervention, although one student felt there was still a place for audio practice in preparing for interpreting in 'more controversial settings'. It is unknown whether the student was referring to cases of sexual abuse, which are usually heard behind closed doors, but it is certainly possible. When asked what they perceived to be the best way to practise interpreting in general, one student made reference to being exposed to 'the speed and accent of spoken English in action'. The latter statement certainly also applies to authentic audiovisual courtroom material used for interpreting practice. Given the fact that such material is relatively easy to produce, the authors recommend that educators in other fields of interpreting replicate the study reported on here. Their students will thank them for it.

\section{Acknowledgments}

The authors would like to thank the Faculty of Culture and Society at Auckland University of Technology for the research grant which made this study possible. They also want to express their gratitude to the technical support person at the School of Language and Culture for his help in preparing the audiovisual clips for interpreting practice. Our thanks also go to Dr Irmengard Wohlfart for translating the abstract and key words into German at very short notice. Lastly, the authors also wish to express their appreciation to all anonymous language assessors who gave feedback on the students' interpreting and last but not least to all participating student interpreters.

\section{Bibliography}

Berk-Seligson, Susan. (2012) The Bilingual Courtroom: Court Interpreters in the Judicial Process. Chicago: University of Chicago Press.

CREZEE, Ineke \& Lynn Grant. (2013) "Missing the Plot? Idiomatic Language in Interpreter Education." International Journal of Interpreter Education 5:1, pp. 17-33.

DANIELS, Harry. (2008) Vygotsky and Research. London: Routledge.

GonzAlez DAVIES, Maria. (2012) "Towards Situated Translation Training: Bridging Academic and Professional Approaches." Unpublished keynote address delivered at the Translation Studies Symposium Training Postgraduate Students 
for the Translation Profession: Didactic Implications and Research Opportunities. University of Auckland.

HALE, Sandra Beatriz. (2004) The Discourse of Court Interpreting: Discourse Practices of the Law, the Witness, and the Interpreter. Amsterdam: John Benjamins.

HALE, Sandra Beatriz. (2010) "Working Effectively With Interpreters in Court." In: Coultard, Malcom \& Alison Johnson (eds.) 2010. The Routledge Handbook of Forensic Linguistics. London: Routledge, pp. 440-454.

HALE, Sandra Beatriz. (2013) Unpublished address given on the occasion of the launch of Introduction to healthcare for interpreters and translators by Ineke Crezee. Auckland University of Technology.

HALE, Sandra Beatriz \& Jemina Napier. (2013) Research Methods in Interpreting: A Practical Resource. Sydney \& London: Bloomsbury.

HALE, Sandra Beatriz \& Stuart Campbell. (2002) "The Interaction Between Text Difficulty and Translation Accuracy." Babel 48:1, pp. 14-33.

JoHn-STEINER, Vera \& Holbrook Mahn. (1996) "Sociocultural Approaches to Learning and Development: A Vygotskian Framework." Educational Psychologist 31, pp.191-206.

Joos, Martin (1968). "The isolation of styles." In: Fishman, Joshua (ed.) 1968. Readings in the Sociology of Language. The Hague: Mouton De Gruyter, pp. 185-191.

KInNUNEn, Tuija. (2011) "Expertise Sharing in the Field of Court Translating and Interpreting." Journal of Applied Language Studies 5:1, pp.92-108.

Kiraly, Don. (2000) A Social Constructivist Approach to Translator Education: Empowerment From Theory to Practice. Manchester: St Jerome.

LAKOFF, Robin. (1985) "My Life in Court." In: Tannen, Deborah \& James E. Alatis (eds.) 1985. Language and Linguistics: The Interdependence of Theory, Data, and Application. Washington, D.C.: Georgetown University, pp. 171-179.

LAVE, Jean \& Eugene Wenger. (1991) Situated Learning: Legitimate Peripheral Participation. Cambridge: Cambridge University Press.

LEE, Jieun. (2009) "Conflicting Views on Court Interpreting Examined through Surveys of Legal Professionals and Court Interpreters." Interpreting 11:1, pp. 35-56.

LiU, Minhua. (2001) Expertise in simultaneous interpreting: A working memory analysis. Austin: University of Texas. Unpublished PhD thesis.

Luchjenbroers, June. (1993) Pragmatic Inference in Language Processing. Melbourne: La Trobe University. Unpublished PhD thesis.

PöchHACKer, Franz. (2010) "Why Interpreting Studies Matters." In: Gile, Daniel; Gyde Hansen \& Nike K. Pokorn (eds.) 2010. Why Translation Studies Matters. Amsterdam: John Benjamins, pp. 3-13.

SPOONLEY, Paul \& Richard Bedford. (2012) Welcome to our World? Immigration and the Reshaping of New Zealand. Auckland: Dunmore. 
Rigney, Azucena C. (1999) "Questioning in Interpreted Testimony." Forensic Linguistics 6:1, pp. 83-108.

RYU, Hokyoung. (2009) "Designing Situated Learning Experiences." In: Ryu, Hokyoung \& David Parsons (eds.) 2009. Innovative Mobile Learning: Techniques and Technologies. Hershey: Information Science Reference, pp. 255-272.

VERTOVEC, Steven. (2007) "Super-diversity and its Implications." Ethnic and Racial Studies 30:6, pp. 1024-1054. Doi: 10.1080/01419870701599465.

WiXson, Karen. (1979) "Miscue Analysis: A Critical Review.” Journal of Literacy Research 11:2, pp. 163-175.

\section{BIONOTES / KURZBIOS}

Dr Ineke Crezee is a Senior Lecturer in Interpreting and Translation at Auckland University of Technology. She is a practising translator and interpreter in medical and legal settings, and the author of several text books including Introduction to Healthcare for Interpreters and Translators. The recipient of many teaching excellence awards, in 2014 she gained a Fulbright Scholar Award to research patient navigators at Seattle Children's Hospital.

Dr. Ineke Crezee ist Senior Lecturer an der Auckland University of Technology in Neuseeland, wo sie in den Fächern Dolmetschen und Übersetzen unterrichtet. Sie arbeitet auch als praktizierende Übersetzerin und Dolmetscherin im medizinischen und juristischen Bereich und ist Autorin mehrerer Bücher, zum Beispiel Introduction to Healthcare for Interpreters and Translators [Einführung ins Gesundheitswesen für Dolmetscher und Übersetzer]. Sie erhielt mehrere Preise für herausragende Leistungen als Lehrkraft, und erhielt 2014 einen Fulbright Scholar Award zur Erforschung der Rolle der interkulturellen Vermittler am Seattle Children's Hospital.

Jo Anna Burn is a Senior Lecturer in Interpreting and Translation at Auckland University of Technology. She is a trained lawyer and has a strong interest in social justice and equity. Her research interests include legal interpreting and first language maintenance in refugee communities.

Jo Anna Burn ist Senior Lecturer für die Fächer Dolmetschen und Übersetzen an der Auckland University of Technology in Neuseeland. Sie ist ausgebildete Anwältin, die sich intensiv für Themen wie soziale Gerechtigkeit und Gleichstellung interessiert. Ihr Forschungsinteresse umfasst das Dolmetschen im juristischen Bereich und die Beibehaltung der Muttersprache in Flüchtlingsgemeinschaften. 
Nidar Gailani is a practising legal interpreter and translator. She has worked in many settings including courts, prisons, police stations and refugee resettlement centres. Her research interests include interpreting of question types in court and refugee resettlement.

Nidar Gailani ist praktizierende Dolmetscherin und Übersetzerin im juristischen Bereich. Ihr vielseitiges Arbeitsumfeld umfasst Gerichtssäle, Gefängnisse, Polizeiwachen und Zentren zur Neuansiedlung von Flüchtlingen. Ihr Forschungsinteresse gilt in erster Linie der Auslegung von Fragetypen vor Gericht und im Zusammenhang mit der Neuansiedlung von Flüchtlingen. 